University of Nebraska - Lincoln

DigitalCommons@University of Nebraska - Lincoln

Faculty Publications: Department of

Entomology

Entomology, Department of

2007

\title{
A Novel Cadherin-Like Gene from Western Corn Rootworm, Diabrotica virgifera virgifera (Coleoptera: Chrysomelidae), Larval Midgut Tissue
}

\author{
A. Sayed \\ EPA \\ E. R. Nekl \\ High Point University \\ H. A. A. Siquiera \\ Universidade Federal Rural de Pernambuco, Departamento de Agronomia - Entomologia, Recife, PE, \\ Brazil
}

H.-C. Wang

University of Nebraska-Lincoln

R. H. ffrench-Constant

University of Exeter, Centre for Ecology and Conservation, Penryn, Cornwall, UK

See next page for additional authors

Follow this and additional works at: https://digitalcommons.unl.edu/entomologyfacpub

Part of the Entomology Commons

Sayed, A.; Nekl, E. R.; Siquiera, H. A. A.; Wang, H.-C.; ffrench-Constant, R. H.; Bagley, M.; and Siegfried, Blair, "A Novel Cadherin-Like Gene from Western Corn Rootworm, Diabrotica virgifera virgifera (Coleoptera: Chrysomelidae), Larval Midgut Tissue" (2007). Faculty Publications: Department of Entomology. 152. https://digitalcommons.unl.edu/entomologyfacpub/152

This Article is brought to you for free and open access by the Entomology, Department of at DigitalCommons@University of Nebraska - Lincoln. It has been accepted for inclusion in Faculty Publications: Department of Entomology by an authorized administrator of DigitalCommons@University of Nebraska - Lincoln. 
Authors

A. Sayed, E. R. Nekl, H. A. A. Siquiera, H.-C. Wang, R. H. ffrench-Constant, M. Bagley, and Blair Siegfried 


\section{A novel cadherin-like gene from western corn rootworm, Diabrotica virgifera virgifera (Coleoptera: Chrysomelidae), larval midgut tissue}

\author{
A. Sayed ${ }^{*}$, E. R. Nekl†, H. A. A. Siqueirał, H.-C. Wang§, \\ R. H. ffrench-Constant $\eta$, M. Bagley ${ }^{\star \star}$ and \\ B. D. Siegfried§ \\ *Dynamac Corporation, c/o US EPA, Cincinnati, OH, USA; \\ †Department of Biology, High Point University, High Point, \\ NC, USA; $\ddagger$ Universidade Federal Rural de Pernambuco, \\ Departamento de Agronomia - Entomologia, Recife, PE, \\ Brazil; §Department of Entomology, University of \\ Nebraska, Lincoln NE, USA; ๆUniversity of Exeter, Centre \\ for Ecology and Conservation, Penryn, Cornwall, UK; and \\ ${ }^{* *}$ National Exposure Research Laboratory, US EPA, \\ Cincinnati, OH, USA
}

\begin{abstract}
A cadherin-like gene associated with larval midgut tissues was cloned from western corn rootworm (Diabrotica virgifera virgifera: Coleoptera), an economically important agricultural pest in North America and Europe and the primary target pest species for corn hybrids expressing Cry3 toxins from Bacillus thuringiensis (Bt). The full-length cDNA (5371 bp in length) encodes an open reading frame for a 1688 amino acid polypeptide. The putative protein has similar architecture to cadherin-like proteins isolated from lepidopteran midguts that have been shown to bind to Cry1 Bt toxins and have been implicated in Bt resistance. The $D$. v. virgifera cadherin-like gene is expressed primarily in the larval midgut and regulated during development, with high levels of expression observed in all instars and adults but not pupae. The corresponding genomic sequence spans more than $90 \mathrm{~kb}$ and is interspersed with 30 large introns. The genomic organization of the cadherin-like gene for this coleopteran species bears strong resemblance to lepidopteran cadherins
\end{abstract}

Received 24 April 2007; accepted after revision 26 June 2007; first published online 28 August 2007. Correspondence: Abu Sayed, Dynamac Corporation, c/o US EPA, Cincinnati, OH 45268, USA. Tel.: 513569 7323; fax: 513569 7554; e-mail: sayed.abu@epa.gov suggesting a common molecular basis for susceptibility to Cry3 toxins in Coleoptera.

Keywords: cadherin, Diabrotica, Bt receptor, insect midgut, exon, intron.

\section{Introduction}

The western corn rootworm, Diabrotica virgifera virgifera LeConte (Coleoptera: Chrysomelidae), is arguably the single most important pest of field corn, Zea mays L. (Levine \& Oloumi-Sadeghi 1991), throughout much of the US Corn Belt and has recently become a major concern in Europe. Managing corn rootworm populations to minimize risk of economic loss has proven extremely difficult, as the insect has demonstrated an apparently unlimited capacity to evolve resistance to small molecule insecticides (Meinke et al., 1998; Parimi et al., 2003; Siegfried et al., 2004) and cultural control practices such as crop rotation (Levine et al., 2002).

Current alternative management technologies include use of transgenic crops that express insecticidal proteins toxic to corn rootworm larvae (Moellenbeck et al., 2001; Ellis et al., 2002). The first transgenic corn hybrids expressing $\delta$-endotoxins from Bacillus thuringiensis $(\mathrm{Bt})$ became commercially available in 2003 (Environmental Protection Agency, 2003). This technology represents a significant departure from traditional crop protection chemistry in that $\mathrm{Bt}$ toxins act on receptors in the insect midgut rather than the insect nervous system. While Bt corn offers a potentially powerful new tool for rootworm management, there are concerns that widespread adoption of such plants will rapidly lead to $\mathrm{Bt}$ toxin resistance and subsequent failure of the control strategy.

Within Lepidoptera, the generally accepted mode of action for Bt toxins involves solubilization of the crystal protein, releasing a $130 \mathrm{kDa}$ protoxin that is activated by proteases in the insect midgut to form a truncated $65 \mathrm{kDa}$ toxin. The target of the activated toxin is the apical (brush border) membrane of larval midgut cells (Bravo et al., 2004). Binding of the activated toxin to midgut specific 
receptors causes a conformational change in the toxin, which allows its insertion into the membrane and formation of ion channels or pores, leading to osmotic imbalance of the insect gut (Schnepf et al., 1998).

In vitro binding assays have implicated cadherin-like proteins as one of the most likely Bt receptor molecules in the midgut membranes of insects. A $210 \mathrm{kDa}$ cadherin-like glycoprotein was identified as a Cry1Ab binding protein in brush border membrane vesicles prepared from midguts of Manduca sexta larvae (Vadlamudi et al., 1993, 1995). In Bombyx mori, a $175 \mathrm{kDa}$ cadherin-like protein was identified as a Cry1Aa binding protein (Nagamatsu et al., 1998a,b; Tsuda et al., 2003). The cadherin-like protein Bt- $\mathrm{R}_{1}(M$. sexta) binds to Cry1A toxins with high affinity (Gómez et al.,

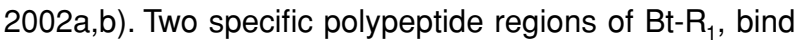
to domain II of Cry1A toxins (Gómez et al., 2003). The proposed model for $\mathrm{Bt}$ toxin receptors consists of one to 12 tandem repeats of homologous extracellular domains called cadherin repeats (CR), a signal peptide that targets the protein to the extracellular matrix, a membrane-proximal extracellular domain, a transmembrane domain, and a cytoplasmic domain (Dorsch et al., 2002).

Expression of a recombinant cadherin-like protein in resistant $B$. mori cells made them sensitive to Cry $1 \mathrm{Aa}$, providing evidence that cadherin-like proteins play a role in Bt toxicity (Nagamatsu et al., 1999). Gahan et al. (2001) reported that Cry $1 \mathrm{Ac}$ resistance in the tobacco budworm, Heliothis virescens, was tightly linked to a cadherin-encoding gene. More recently, Morin et al. (2003) reported three different cadherin alleles from the pink bollworm, Pectinophora gossypiella, that were linked with resistance to Cry1Ac and survival on transgenic cotton that expresses Cry $1 \mathrm{Ac}$.

The $\delta$-endotoxins from Bt that comprise the class Cry3 genes from $B$. thuringiensis subsp. tenebrionis, san diego, morrisoni, tolworthl and gallariae encode for the Cry3A, Cry3B and Cry3C group of proteins, which exhibit coleopteran specific activity (Krieg et al., 1983; Hernstadt et al., 1986, 1987; Sick et al., 1990). In contrast to lepidopterans, little is known regarding specific target sites for Cry3 toxins in the coleopteran midgut. However, recent work with the Colorado potato beetle, Leptinotarsa decemlineata, has shown that pore formation activity of Cry3 toxins is dependent on toxin interaction with the brush border membranes followed by oligomeric pre-pore structure formation, similar to observations of Cry1A toxicity in Lepidoptera (Rausell et al., 2004). This general mechanism of toxin activation through membrane insertion suggests a common mode of action among different Cry toxin families.

In this paper, we describe cloning of the first coleopteran cadherin-like gene from the western corn rootworm, Diabrotica virgifera virgifera. We describe its expression pattern during development and in different tissues and assess its polypeptide and genomic architecture relative to other insect cadherin-like proteins.

\section{Results}

Cloning of cadherin-like cDNA in Diabrotica virgifera virgifera Oligonucleotide primers designed from a previously isolated D. v. virgifera cadherin EST (Siegfried et al., 2005) were used to clone the full-length cadherin-like cDNA resulting in the isolation of a $5371 \mathrm{nt}$ transcript (GenBank accession no. EF531715). When translated, the open-reading frame consisted of 1688 amino acids with a predicted molecular mass of $191 \mathrm{kDa}$ and a calculated pl of 4.44 (Fig. 1). Several 5'-RACE and RLM-RACE experiments were carried out but no $5^{\prime}$ untranslated region longer than that shown in Fig. 2 was obtained, suggesting that the adenine residue $135 \mathrm{bp}$ upstream of the ATG start codon is the transcription start site (designated as position +1 in Fig. 2). Analysis of the predicted protein sequence revealed 10 highly conserved cadherin-like repeats, 27 putative $\mathrm{N}$-glycosylation sites, a membrane proximal region (aa: 1329-1569), a transmembrane region (aa: 1570-1593) and a cytosolic region (aa: 1594-1688) (Fig. 1). A signal peptide cleavage site was located at the $\mathrm{N}$-terminus (aa: 22-23).

To confirm the functionality of the translation initiation site, the full-length coding sequence was expressed in Sf21 insect cell culture using baculovirus cloning and expression systems. Recombinantly expressed protein was identified by Western blotting with an antibody raised against the WCR cadherin-like peptide (Fig. 3). The higher than expected molecular weight indicates substantial post-translational modification (e.g. glycosylation).

\section{Identification of putative Bt-binding regions}

Using previously identified Bt toxin binding regions TBR1 (NITIHITDTNN) and TBR2 (SILTVTVT) reported for $M$. sexta as a guide (Gómez et al., 2002a) we identified conserved binding motifs located near amino acid positions 850 (TBR1) and 1320 (TBR2) in various lepidopteran cadherinlike proteins (Fig. 4). Importantly, pattern searches of the $D$. v. virgifera cadherin sequence revealed two similar potential toxin binding regions: ${ }^{833}$ DISIYVIDTNN ${ }^{843}$ and ${ }^{1311}$ SSLNVTVN ${ }^{1318}$ (Fig. 4).

We tested the conservation of putative TBR1 and TBR2 sites in the related Mexican corn rootworm (MCR) D. v. zeae by cloning and sequencing a 1592 bp cDNA fragment (GenBank accession no. EF541348) using primers derived from the WCR cadherin-like cDNA sequence. As expected, the MCR cDNA has high sequence identity (99\%) with WCR over the analysed region (base positions 2631-4222). The deduced 530 aa cadherin-like protein also is $99 \%$ identical in the analysed region (positions 824-1353) and contains TBR1 and TBR2 motifs, which are $100 \%$ identical to those from WCR.

\section{Midgut specific expression of cadherin-like protein}

The expression of the cadherin-like gene was examined using Northern blot analysis among the various developmental 
SIG

MATRNLCLCMLIWMPLFEGIVGDVAFGIAQIPGGKATVEDLKKGKYLLNMEENNHGGVIPTPLFTITGVDNTDCPNLNVE 80 FTQGMKFKFS INESCIFYAEQTFDYESNERSYNFRISKSVNDEIDIAFS IKNIDDEPPQLGTFKCNFNEQLDYSLDDTPC 160

NTTLHDPDGWLAQEKILIFIDTKDEDIFAIDLRKPLPNDTGTDTYVFMYLLKQLNYEDTNFYQFTVQANDSGGNLSPQES 240

AVVNVINIRSRPPKWSKITLFDQFDELTEQDYDIQALDGDTGIHADICYAKLGEDLPDNYINVSTDKTNKKGHIHVNPID 320 CR2

RDKDDLTLYHFNISAYVCDAPDYFTVNTVQYYIIDIDNNPPRIVENVGDDGKNTTFDDDNDHKNVTLSYLENYSRSYNFS

TTITDRDTGENAQFTVSLENVEGSTVDYTQPYLIVPDNAYKTGSFI ISVKNKTFLDFENDTWKKHSYYVVSNGKKDKSKT 480

CR3

DRMLISVSLEDYNDELPIFEKESYTTEINETVANGTQILYTHATDRDAEDFELKMNIVGTYAENRLSIDKDGNIKVEVVN CR4

AFDYDVLNSVYFOVTATDKVNHVTRVPVTINILDVNNEAPVINQKDHIQIEENQQNGVVLNVTITATDVDTTANLTATIN CR5

WEDSKVTKTNGAVVKTDAVIKAMQFLEIENTQTDDGLEMKLKVINNNDDNPDKPDFETFDTLYLS IVVEDRNTDPDFEQN RYTEGQIVINILDVNDNPPYFPPSNDDTRQVQEMSLKGVSVGS IKAVDVDLNSEITYHCTPEYEKFDWVDVNLTTGAITV KNDKQVDADTDKTYYFNYTCWAHDGVFFSKPLDISIYVIDTNNEVPVIDFRNEVHVKEKSLIDTVIKKIVTSDLDRDEPF

RTVNCNFASDTDPDCQIEFYIDTNVLKVKRNKTLDRDKGRKTYPCLFECLDNPLNVRSQGQNKANKSFTI ILDDINDHAP

VLMTKDLQCSENLNKDGEVGEGI IGEDIDDGDNAKIDFSVLS IVDKETKNDIQESFNISKIDSDYVLNDTLKKVHLIAFE 1040

CR8

DLKGKYGTYEVTLHMHDEGDPMQTTDPDPTLTLTIEKWNYQTPS I IFPENDQTYIVLSDQQPGQPLALFNNTGTSNTLPD

CR9

FSATDGETKDYSKWDVKFSYTQTNYEDDKIFVIDHIQPCVSQLQVSKHFNSDLVRSKKYKLTITASVKDGAEQEGEAGYS

TSANISIVFLNNDAQPIFQNSDWSVSFVEFNTTQPAKPLEEQAEYENTKGGLP IYYHFYSENQTLSKYFEVDETSGDLSV CR10

IGNLTYDYDQDISFHIVASNDSQVRMLDPRSSLNVTVNFLPRNRRAPQWKSTKFFGAVMPTFVTGNLIVTAQAHDDDYID MPR

QQRGLTCSISSEINRIGEGLDKI IGEPFYLSTENDAAKIFLDFTVQTTMTGRFEFKIKVEDNRDDYGNGPFESEADTTIF

IITKDNTVDFQFYNDIEDVQDRETPMLKI ISDIVGYDAYRQNIDTVTNSGLVRTRARLYFIDSKSSRRLQLTKSPADSGF

Figure 1. Deduced amino acid sequence of the Diabrotica virgifera virgifera cadherin-like protein. The putative signal peptide (SIG) is in italic fonts. Cadherin repeats (CR) are indicated by arrows. MPR, membrane proximal region; TMR, transmembrane repeats; and CytoR, cytosolic region. Bold denotes predicted putative $\mathrm{N}$-glycosylation sites.

stages of D. v. virgifera (first, second, third instar, pupae and adults). The transcript is most abundant in first, second and third instars but appears to be downregulated in pupae before being upregulated again in adults (Fig. 5A). Analysis of the cadherin-like RNA in larval tissues indicates that expression is limited to midgut tissues as it was not detected in integument or fat body (Fig. 5B).

\section{Phylogenetic analysis}

Although the deduced $D$. v. virgifera aa sequences shares common architectural themes with lepidopteran cadherinlike proteins that have been identified as putative $\mathrm{Bt}$ toxin receptors, phylogenetic analysis revealed that this putative receptor has only $22-25 \%$ sequence identity with Lepidopteran cadherins (Fig.6). As expected, the predicted protein was most closely related to another coleopteran cadherin-like protein identified from Tribolium castaneum (red flour beetle) with $30 \%$ identity.

\section{Characterization of genomic structure}

By genome walking along WCR cadherin-like gene, we have identified 30 introns, the four smallest of which were fully sequenced: introns 6 (655 bp), 11 (1990 bp), 28 (2207 bp) and 29 (1821 bp) (GenBank accession no. EF541349). Most of the other introns were very long and were progressively cloned and sequenced. Between 3 and $5 \mathrm{~kb}$ of sequence information was obtained for each of the other introns. BLAST analysis of the WCR intron sequences against sequence databases did not reveal significant homology with any known sequence. The intron sequences 


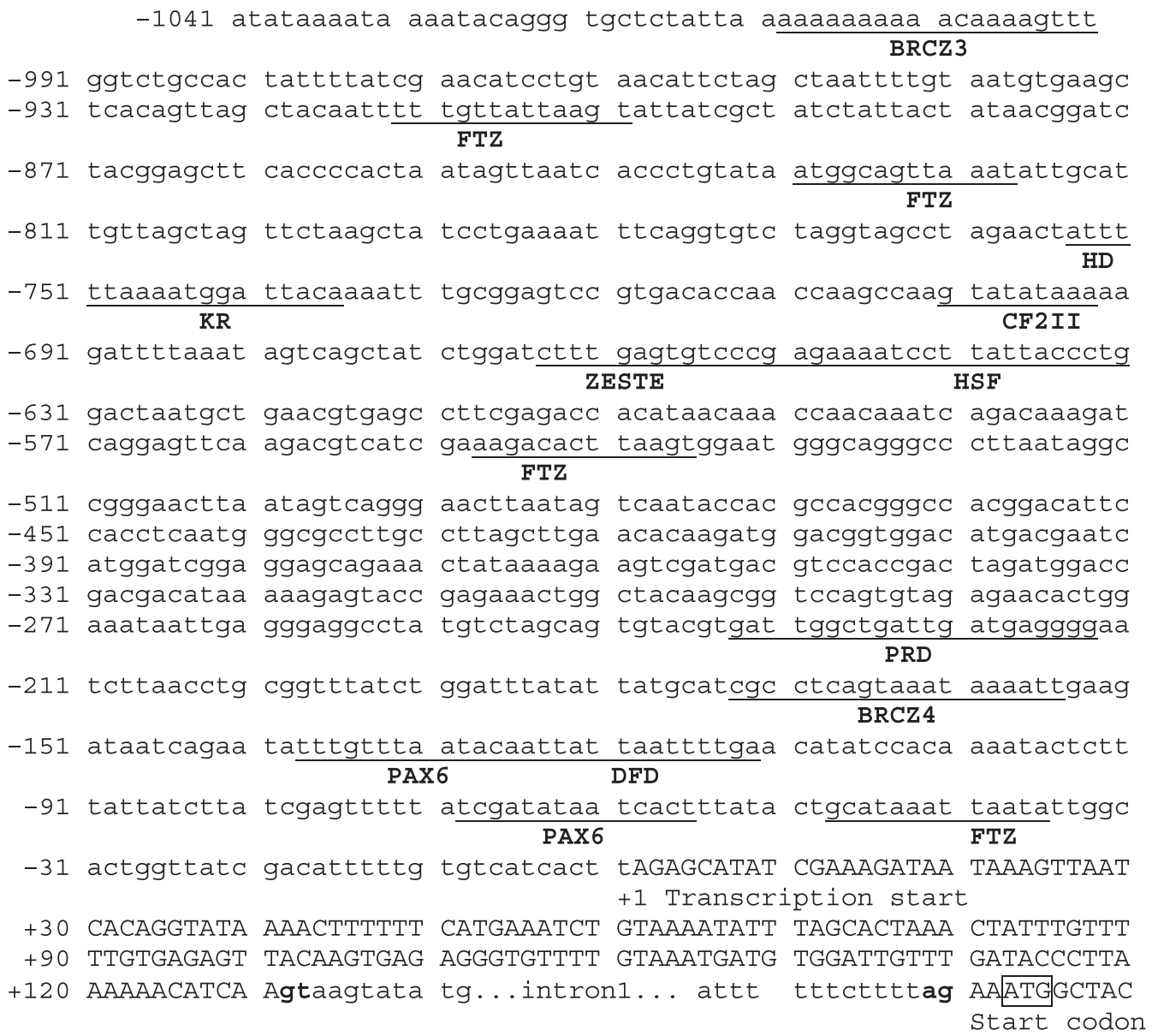

Figure 2. An approximately $1 \mathrm{~kb}$ section of the upstream regulatory genomic sequence of the cadherin-like gene. The exon sequence is shown in upper case. The transcription start site is designated as position +1 . Potential transcription factor binding sites, as revealed by the Matlnspector computer program, are underlined. Only a portion of the first intron (with splice donor and acceptor GT-AG nucleotides in bold) is shown. The translation start codon ATG is boxed.

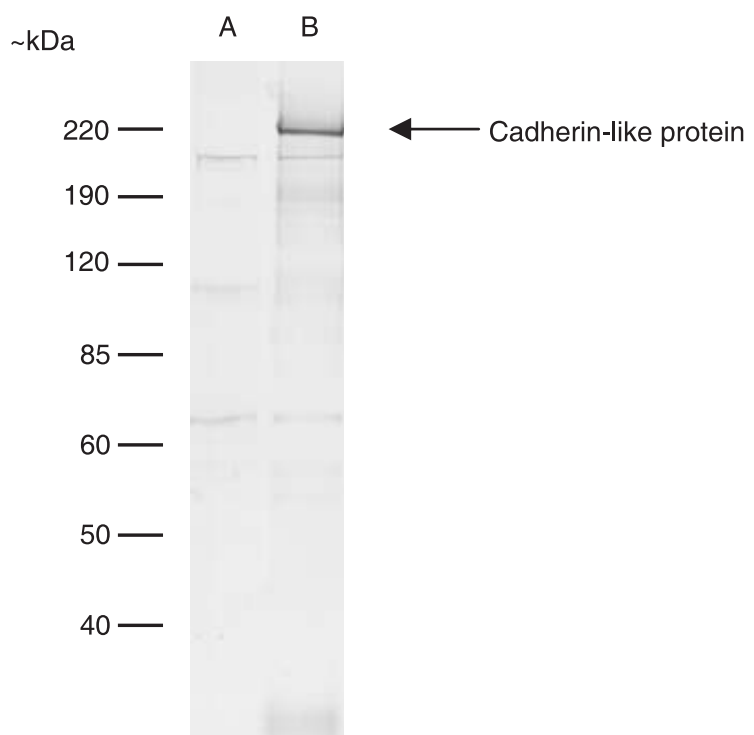

Figure 3. Expression of full-length cadherin-like protein in sf21 cell culture. The transiently expressed protein was immunoblotted with polyclonal antibody for the cadherin-like protein. Lane A: extracts from cells transfected with control vector only. B: extracts from cells transfected with recombinant vector. delineated 31 exons that ranged from 57 (exon 1) to $414 \mathrm{bp}$ (exon 24). The first exon is a noncoding exon and is designated exon-1 in Table 1. The translation start site maps to the third base of exon 1 and the protein translation stop codon is located at the $95 \mathrm{bp}$ of exon 30 . All of the exon-intron boundary sequences conform to the consensus splice donor $(\underline{G T})$ and acceptor $(\underline{A G})$ sites (Table 1). With very few exceptions, conserved sequences of $G T A A G(T / A)$ were observed at the $3^{\prime}$ splice donor sites and $(A / C) T_{n}(A / C) \underline{A G}$ or $(A / C) T_{n} A G$ sequences was identified at the $5^{\prime}$ splice acceptor sites (Table 1).

To identify the putative regulatory region within the $5^{\prime}$ flanking DNA, a 2371 bp genomic DNA fragment upstream from exon 1 was sequenced. As shown in Fig. 2, results of analyses with the MatInspector revealed several transcription factor binding sites within the $1 \mathrm{~kb}$ upstream of $5^{\prime}$-flanking region. These include four FTZ and two PAX6 sites. The fushi tarzu (Ftz) homeoprotein targets the majority of the genes in Drosophila (Liang \& Biggin, 1998; Bowler et al. 2006). Interestingly, mouse R-cadherin was shown to be regulated by Pax6 transcription factor (Andrews \& Mastick, 
Position (aa)

\begin{tabular}{lc}
\multicolumn{2}{c}{ Position (aa) } \\
TBR1 \\
$>$ Manduca & 855-PPDPTYWETEGNITIHITDTNNKVPQAETTKFDTVVYIYENA \\
$>$ Bombyx & 856 -PDDPTYWETPGQVVIQIIDTNNKIPQPETDQFKAVVYIYEDA \\
$>$ Heliothis & 861 -PPDPNYFNTPGDITIHITDTNNRVPRVEEDKFEEIVYIYEGA \\
$>$ Helicoverpa & 861 -PPDPTYFETPGEITIHITDTNNKVPQVEDDKFEATVYIYEGA \\
$>$ LYmantria & 860 -PPDPTYWETEGLISIYIIDTNNKIPQAEIELFSTTVYVWENA \\
$>$ Pectinophora & 861 -PPDPVFWDTLGDNVINIVDINNKVPAADLSRFNETVYIYENA \\
$>$ Chilo & 853 -PPDPMHFNTTGYIQIEILDTNNKVPRGTLGPIQVGGAHQREI \\
$>$ Ostrinia & 847 -PPDPNYFEVPGDIEIEIIDTNNKVPEPLTEKFNTTVYVWENA \\
$>$ WCR & $822-$ AHDGVFFSKPLDISIYVIDTNNEVPVIDFPNEVHVKEKSLID \\
$>$ MCR & $?-$ AHDGVFFSKPLDISIYVIDTNNEVPVIDFPNEVHVKEKSLID
\end{tabular}

Figure 4. Amino acid alignment of putative Bt toxin binding regions (TBRs). Known Manduca sexta cadherin-like protein motifs TBR1 and TBR2 were used to identify similar domains in cadherin-like proteins from other lepidopteran species, e.g. Bombyx mori, Heliothis virescens, Helicoverpa armigera, Lymantria dispar, Pectinophora gossypiella, Chilo suppressalis, Ostrinia nubilalis. This alignment was then used to identify TBR motifs in Diabrotica cadherin-like proteins from western and Mexican corn rootworms cloned in this study.
TBR2

$>$ Manduca 1322-VAASNSPD-GGIPLPASILTVTVTVREADPRPVFMRELYTAGIST $>$ Bombyx 1321-IAASNSPT-GGIALT-STITITVNVREADPQPYFVRDLYTAGIST $>$ Heliothis 1329-IGASDSPSP-AAVLQASTLTVTVNVREANPRPVFQSALYTAGIST $>$ Helicoverpa 1329-IGASDTPN-PAAVLQASTLTVTVNVREANPRPVFQRALYTAGISA > Lymantria 1325-VAASNSPD-SVNALPSNTLTVTVNVREANPRPMFTSEEYMAGIST $>$ Pectinophora 1330-VAASNSPTGGGIPLPGSLLTVTVTVREADPRPVFEQRLYTAGIST $>$ Chilo 1317-VAASNSPSATGTPLDGTTLTVTINVVEEDPRPVFERELYTAGISV > Ostrinia 1318-IAASNSPDATGIPLQTSILVVTINVREANPRPIFEQDLYTAVIST $>$ WCR 1296 -IVASNDSQVRMLDPRSSLNVTVNFLPRNRRAPQWKSTKFFGAVM

$>$ MCR ?-IVASNDSQVRMLDPRSSLNVTVNFLPRNRRAPQWKSTKFFGAVM

Table 1. Genomic organization of the cadherin-like gene (GenBank accession EF541349). Exon sizes are shown. All intron-exon junctions followed the GT-AG rule for RNA splicing. The $5^{\prime}$ acceptor and the $3^{\prime}$ donor splice sites are shown. Exon sequences are shown in upper case. The size of the coding region is indicated in parentheses for the first and last exon

\begin{tabular}{|c|c|c|c|}
\hline \multicolumn{2}{|c|}{ Exon } & \multicolumn{2}{|l|}{ Intron/exon junction } \\
\hline No. & Size (bp) & 5'-Acceptor & 3'-Donor \\
\hline-1 & 160 & & ACATCAAgtaagtat \\
\hline 1 & $57(55)$ & gtttttatttttcttttagAAATGGCTACGAGAAATCTA & TTTGAGGgtaagtat \\
\hline 2 & 165 & tgcctacatttactttttagGCATAGTTGGCGACGTCGCC & ACTGATTgtaagtaa \\
\hline 3 & 224 & aactaactgaatattttcagGTCCTAACTTGAATGTTGAA & CTTTAATgtaagtac \\
\hline 4 & 107 & ttcattatttatatttttagGAACAATTAGACTATAGTCTT & CACTAAGgttagaaa \\
\hline 5 & 138 & attttaaattaatcttttagGATGAAGATATATTCGCAAT & AGCAAATgtaagaaa \\
\hline 6 & 123 & tttattttttttatttttagGATTCTGGAGGTAATCTTTC & CGAACAAgtaagtta \\
\hline 7 & 82 & ttcatttacgatttttgcagGATTACGATATACAAGCTTT & TTACCAGgtgagtaa \\
\hline 8 & 332 & atcattttatatttttttagACAATTACATAAACGTCAGT & AGATACGgtaagtag \\
\hline 9 & 180 & acattttctattaattttagGGCGAAAACGCGCAATTCAC & CTATTATgtaagaaa \\
\hline 10 & 197 & attgaaataaaatatttttagGTTGTTTCCAATGGAAAAAA & AACTGAAgtaagtat \\
\hline 11 & 211 & tacatatattttctttttagAATGAATATAGTTGGAACTT & AAATCAAgtaagaaa \\
\hline 12 & 179 & gacgctgtcatttatttttagGTGGACCATATACAAATCGA & CTATGCAgtaagtct \\
\hline 13 & 182 & tatatttatattatgttttagATTTTTAGAGATAGAAAATA & ACAGAAGgtaagtaa \\
\hline 14 & 166 & ttaattttcatttttattagGTCAAATTGTCATCAATATC & ATTGCACgtaagtat \\
\hline 15 & 160 & tatgtagtagcttattttagGCCCGAATATGAAAAGTTT & GTTAGACgtaagtat \\
\hline 16 & 133 & tctacatttattatatttagATCTCAATCTATGTCATCGA & AGAGATGgtaagaac \\
\hline 17 & 171 & acttttttttaatatttcagAGCCGTTTCGTACTGTAAAC & CCTTTAAgtaagtgt \\
\hline 18 & 122 & agctaaaatttaattttcagATGTTCGATCCCAAGGACAA & GAATAAGgtatgtgc \\
\hline 19 & 237 & acctagttatttttttttagGACGGCGAAGTAGGAGAGGG & TTTACACgtaagttt \\
\hline 20 & 132 & cagtatgactatttgtttagATGCATGACGAAGGAGATCC & CCTATCGgtaagaaa \\
\hline 21 & 142 & ataatattaaactattttagGATCAACAACCTGGTCAACC & AATTATGgtaagttg \\
\hline 22 & 104 & tgcgttgatttatattttagAAGATGATAAAATTTTCGTG & GTATAAGgtaatatt \\
\hline 23 & 414 & taatctttgctcaattttcagCTAACTATTACAGCCAGTGT & TGTTAATgtaagtac \\
\hline 24 & 102 & aattatttgttgattttagTTTCTTCCACGTAACCGCA & CGCTCAAgtaagtat \\
\hline 25 & 229 & atatatattttttacttccagGCTCATGACGACGATTATAT & GGCAATGgtaagaat \\
\hline 26 & 110 & tttacgaatactgtattttagGTCCATTTGAAAGTGAAGCT & AACACCGgtatgtat \\
\hline 27 & 194 & tataaaaactacttttccagATGTTAAAAATAATATCCGA & TATTAAAgttagtaa \\
\hline 28 & 201 & tttggcttaatatatttcagCATAGTGACCAATGTGAACA & CCAGACAgtaagtaa \\
\hline 29 & 180 & aaacaaaaataaaaaatttcagGTTAAGTAACAGAATTAAAA & CTCACAGgtaagttt \\
\hline 30 & $239(94)$ & ttatttcgtaatattttagCATAAGAAGCGGTGATTCTG & \\
\hline
\end{tabular}

2003). The sequence GCATATC at position +3 closely resembles a consensus initiator element (Inr) (YYANWYY, where $\mathrm{Y} ; \mathrm{C}$ or $\mathrm{T}$, and $\mathrm{W}$; A or T). No canonical TATA box is present immediate upstream of transcription start site although a highly AT-enriched sequence is present around the expected $-40 \mathrm{bp}$ region. This phenomenon is common in house-keeping genes and several cadherin genes lacking the TATA box have been previously reported (Behrens et al., 
A

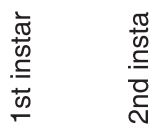

$\frac{\bar{\sigma}}{\omega}$
$\frac{.}{5}$
$\frac{0}{0}$

$\stackrel{0}{0}$
$\stackrel{+}{2}$

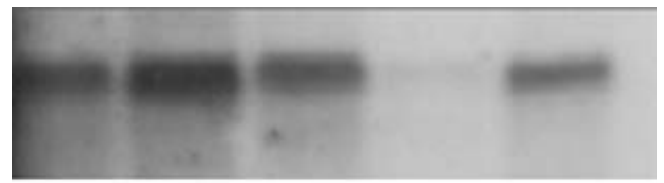

Cadherin

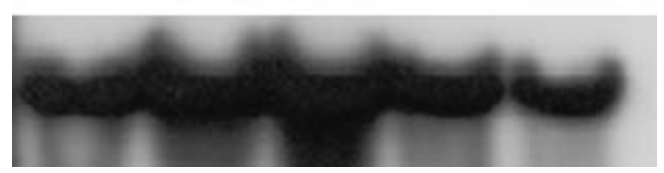

$\beta$-Actin

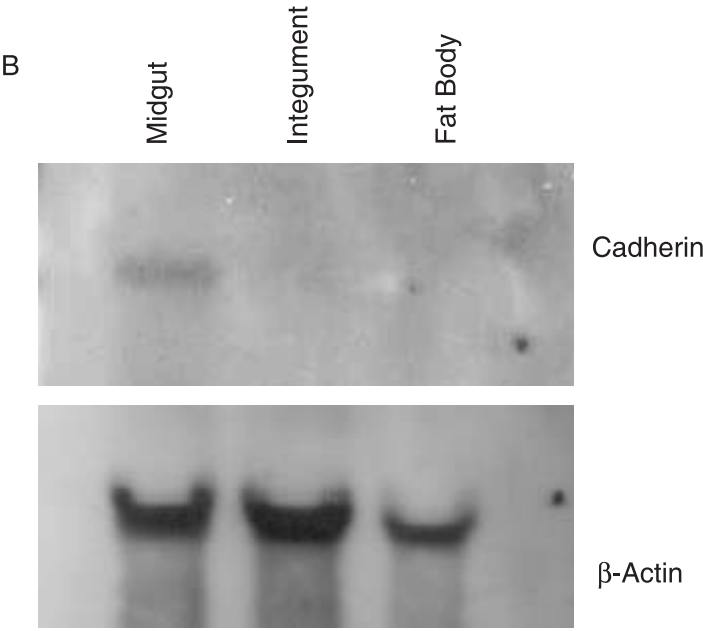

Figure 5. Northern blot analysis of Diabrotica virgifera virgifera RNA. Blots were probed with a DIG-labelled cadherin probe generated from the cadherin sequence and a Diabrotica virgifera virgifera actin for standardized loading. Total RNA $(10 \mu \mathrm{g})$ was loaded in each lane. (A) RNA isolated from first, second, third instars, pupae and adults. (B) RNA isolated from midgut, integument and fat body.

1991; Faraldo \& Cano 1993; Silos et al., 1996; Whyte et al., 1999).

Table 2 provides a comparative genomic overview of an exemplar lepidopteran cadherin-like gene (from the silkworm Bombyx mori) and the WCR cadherin-like gene described here. In contrast to the 31 exons and 30 introns we identified for WCR, lepidopteran cadherin-like genes are composed of 35 exons and 34 introns. Our genomic sequence information suggests that the $D$. v. virgifera cadherinlike gene spans over $90 \mathrm{~kb}$, much larger than the reported sizes for lepidopteran cadherin-like genes (20-40 kb).

\section{Discussion}

Cadherins represent a large and diverse family of glycoproteins that are present in vertebrates and invertebrates and are essential for a number of cellular processes. These proteins are involved in mediating cell adhesion and play a fundamental part in normal development by participating in
Table 2. Similarities in the domain structure of lepidopteran (Bombyx morl) and coleopteran (Diabrotica virgifera) cadherin-like proteins. The location of cadherin repeats (CR) in multiple exons, exons encoding signal peptide (SIG) and transmembrane (TM) regions are indicated

\begin{tabular}{|c|c|c|c|c|}
\hline \multirow{2}{*}{$\begin{array}{l}\text { Exon } \\
\text { No. }\end{array}$} & \multicolumn{2}{|c|}{ Bombyx mori ${ }^{*}$} & \multicolumn{2}{|c|}{ Diabrotica virgifera virgifera } \\
\hline & Position & Function & Position & Function \\
\hline-1 & $1-83$ & & $1-160$ & \\
\hline 1 & $84-175$ & SIG & $161-217$ & SIG \\
\hline 2 & $176-244$ & & $218-382$ & \\
\hline 3 & $245-403$ & & $383-606$ & \\
\hline 4 & $404-521$ & & $607-711$ & CR1 \\
\hline 5 & $522-669$ & & $712-849$ & CR1 \\
\hline 6 & $670-906$ & CR1 & $850-972$ & \\
\hline 7 & $907-1105$ & CR1, CR2 & $973-1054$ & CR2 \\
\hline 8 & $1106-1395$ & CR2 & $1055-1386$ & CR2 \\
\hline 9 & $1396-1569$ & CR3 & $1387-1566$ & CR3 \\
\hline 10 & $1570-1763$ & CR3 & $1567-1763$ & CR3, CR4 \\
\hline 11 & $1764-1881$ & CR4 & $1764-1974$ & CR4 \\
\hline 12 & $1882-1983$ & CR4 & $1975-2153$ & CR5 \\
\hline 13 & $1984-2153$ & & $2154-2335$ & CR5 \\
\hline 14 & 2154-2332 & CR5 & $2336-2501$ & CR5 \\
\hline 15 & $2333-2507$ & CR5 & $2502-2661$ & CR6 \\
\hline 16 & $2508-2709$ & CR6 & $2662-2794$ & CR6, TBR1 \\
\hline 17 & $2710-2851$ & CR6, TBR1 & 2795-2965 & CR7 \\
\hline 18 & $2852-3043$ & CR7 & $2966-3077$ & CR7, CR8 \\
\hline 19 & $3044-3165$ & $\mathrm{CR} 7$ & $3078-3324$ & CR8 \\
\hline 20 & $3166-3384$ & CR8 & $3325-3456$ & \\
\hline 21 & $3385-3510$ & CR8 & $3457-3598$ & CR9 \\
\hline 22 & $3511-3631$ & CR9 & $3599-3702$ & CR9 \\
\hline 23 & $3632-3729$ & CR9 & $3703-4116$ & CR9, CR10, TBR2 \\
\hline 24 & $3730-3862$ & CR9 & $4117-4218$ & CR10 \\
\hline 25 & $3863-3967$ & & $4219-4447$ & \\
\hline 26 & $3968-4134$ & CR10 & $4448-4557$ & \\
\hline 27 & $4135-4233$ & CR10, TBR2 & $4558-4751$ & \\
\hline 28 & $4234-4426$ & & $4752-4952$ & TM \\
\hline 29 & $4427-4536$ & & $4953-5132$ & \\
\hline 30 & $4537-4694$ & & $5133-5371$ & \\
\hline 31 & $4695-4898$ & TM & & \\
\hline 32 & $4899-5063$ & & & \\
\hline 33 & $5064-5166$ & & & \\
\hline 34 & $5167-5471$ & & & \\
\hline
\end{tabular}

${ }^{*} B$. mori data were extrapolated from the published report (Bel \& Escriche, 2006).

the maintenance of proper cell-cell contacts in vertebrates (Gumbiner, 2005) and invertebrates such as Drosophila (Godt \& Tepass, 1998). At present, cadherin proteins identified from insect midguts have not been extensively studied and a function other than as receptors for $\mathrm{Bt}$ toxins has not been definitively assigned. In Lepidoptera, cadherins are not only specific receptors for the toxins, but also facilitate a post binding specific proteolytic cleavage step that induces toxin oligomerization and pore formation (Griffitts \& Aroian, 2005).

Here, we have characterized the full cDNA sequence, the location of intron-exon boundaries and the $5^{\prime}$-untranslated region, including the promoter. To our knowledge, this is the first report of cloning of a cadherin-like gene from a Coleoptera. Despite relatively low sequence identity with lepidopetran receptors, the putative $D$. virgifera receptor 
Figure 6. Unrooted neighbour-joining tree of aligned cDNA sequences for Diabrotica virgifera virgifera (Dvv) and Lepidoptera cadherin-like proteins identified as Cry1 receptors, along with a predicted cadherin sequence for Triboleum castaneum. Bootstrap support values for interior nodes are provided. The distance analysis was performed with MEGA version 3.1 (Kumar et al., 2004). GenBank accession numbers are displayed within the tree. $\mathrm{Pg}$, P. gossypiella; Ld, L. dispar, Ms, M. sexta; Bm, B. mori; $\mathrm{Hv}, H$. virescens; Ha, H. armigera; $\mathrm{Hz}, H$. zea; Dvv, D. v. virgifera; $\mathrm{Ai}, A$. ipsilon; $\mathrm{Sf}, \mathrm{S}$. frugiperda; $\mathrm{Cs}, C$. suppressalis; On, O. nubilalis; Of, O. funarcalis; Tc, T. castaneum.

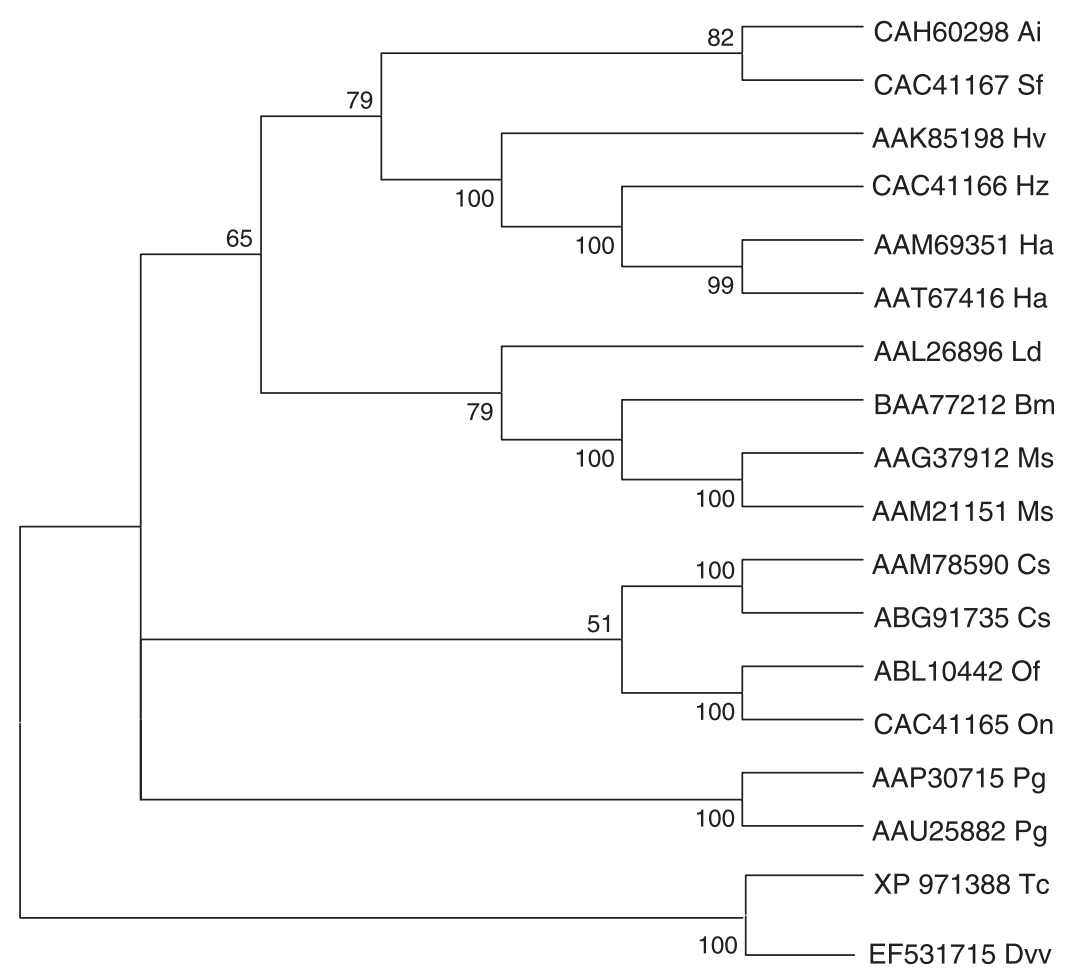

shares striking similarities in protein architecture and genomic composition. Importantly, we have identified putative Btbinding regions that are similar in amino acid sequence to those identified in lepidopteran cadherin-like proteins. As with other insects, expression of the protein is predominantly in midgut tissue. We observed expression of the gene during both larval and adult developmental stages. Because corn rootworms are susceptible to the Cry toxins only during larval stages (Nowatzki et al., 2006), differences in the gut environment between adults and larvae may be responsible for larval specificity of the toxin. Finally, we found that the gene is remarkably well conserved between western and Mexican corn rootworms, including $100 \%$ amino acid homology within the putative Bt-binding regions.

Recently, a report was published by Bel \& Escriche (2006) that discusses the genomic structure of cadherinlike genes in lepidopteran species. A priori this difference observed between Coleoptera and Lepidoptera cadherinlike genes may be expected considering the observed size heterogeneity even among the lepidopteran genes from O. nubilalis, $H$. armigera and $B$. mori $(19.6 \mathrm{~kb}, 20.0 \mathrm{~kb}$ and $41.8 \mathrm{~kb}$, respectively). Although intron size differences are large, the gene organization is very similar for these two orders of insects. For example, exon-intron organization, the number of exons, exon sizes, and the presence of noncoding first exons are all very similar. Homogeneity was also observed in the distribution of functional motifs such as amino terminal signal peptides (SIG), cadherin repeats
(CR), predicted Bt toxin binding sites (TBR1 and TBR2) and carboxy terminal transmembrane coding regions (TM). Without exception, all of the cadherin repeats are encoded by multiple exons that span intron boundaries. Considering these structural similarities, it is highly likely that coleopteran and lepidopteran Bt-related cadherin-like genes share evolutionary conserved genomic and functional structure. Exploitation of this evolutionary conservation will be of great utility in interpreting molecular mechanisms of Bt toxicity and resistance in Coleoptera.

\section{Experimental procedures}

\section{Full-length cDNA cloning}

Total RNA was isolated from excised midguts of second instar $D$. v. virgifera using TRIzol Reagent (Invitrogen Life Technologies, Carlsbad, CA) according to the manufacturer's instructions. Genespecific primers (CLP-1: AATCGTCGTCATGAGCTTGAGCGGTGAC, and CLP-2: TCCACTGAGGAGCTCTGCGGTTACGTGG) were designed from a $D$. v. virgifera EST sequence (Siegfried et al., 2005) and used in 5'-RACE with the SMART RACE kit (Clontech, Palo Alto, CA) according to the manufacturer's instructions. Two micrograms of total RNA was reverse transcribed with BD PowerScript Reverse Transcriptase at $42^{\circ} \mathrm{C}$ for $1.5 \mathrm{~h}$ to synthesize first strand $5^{\prime}$-RACE-Ready CDNA in the presence of $5^{\prime}$ CDS primer and the SMART II oligo (Clontech). The 5'-RACE polymerase chain reaction (PCR) product was amplified from $2 \mu \mathrm{l}$ of cDNA by PCR using CLP1 and the $5^{\prime}$-RACE adaptor primer (UPM). Two $\mu$ l of the diluted (50-fold) PCR product was used in a nested PCR with CLP2 and the nested adaptor primer (NUP). These two amplifications were performed with $10 \mu \mathrm{M}$ CLP1 (or CLP2) and UPM (or NUP), $10 \mathrm{mM}$ 
of each dNTP and $1 \times$ Advantage cDNA Polymerase Mix (Clontech). PCR was performed with 35 cycles of $95^{\circ} \mathrm{C}$ for $2 \mathrm{~s}, 68^{\circ} \mathrm{C}$ for $4 \mathrm{~min}$, followed by a final terminal extension step for $10 \mathrm{~min}$ at $68^{\circ} \mathrm{C}$. The final PCR product was cloned into the PCR 2.1 TOPO TA vector (Invitrogen) and sequenced using vector and gene specific primers. The transcription start point was independently determined using the oligocapping method of RNA Ligase-Mediated Rapid Amplification of $5^{\prime}$ cDNA Ends (RLM-RACE) in the GeneRacer kit (Invitrogen). Total RNA was dephosphorylated by calf intestine alkaline phosphatase and treated with tobacco acid phosphatase to remove the $5^{\prime}$ cap structure of mRNA followed by ligation to an RNA oligonucleotide. After the cDNA was synthesized from oligo-dT primers, an initial PCR was performed using the RACE outer genespecific primer 5'-TTCTCTTGTGCCAGCCATCCGTCGGGATC and the outer RNA adaptor primer in the kit. The RACE inner genespecific primer 5'-TTGTGCCAGCCATCCGTCGGGATCATGCA and the inner RNA adaptor primer in the kit were used in the final PCR. PCR conditions were as follows: five cycles of $95^{\circ} \mathrm{C}$ for $2 \mathrm{~s}$, $72{ }^{\circ} \mathrm{C}$ for $1 \mathrm{~min}$; five cycles of $95^{\circ} \mathrm{C}$ for $2 \mathrm{~s}, 70^{\circ} \mathrm{C}$ for $1 \mathrm{~min}$ : and 25 cycles of $95^{\circ} \mathrm{C}$ for $2 \mathrm{~s}, 68^{\circ} \mathrm{C}$ for $1 \mathrm{~min}$. Amplified fragments were cloned in TOPO vector for sequencing.

\section{Expression of cadherin-like protein in insect cell culture}

Two micrograms total RNA that was isolated from WCR midgut tissue was subjected to reverse transcription with 18-mer oligo-dT for $1 \mathrm{~h}$ at $55^{\circ} \mathrm{C}$ in a $20 \mu \mathrm{l}$ reaction using Superscript III Reverse Transcriptase (Invitrogen) according to the manufacturer's protocol. The full-length cadherin-like mRNA was PCR amplified with forward (5'-GTAAATGATGTGGATTGTTTGATACCCT) and reverse (5'-ATCTATTAAGACCAACTTAAGCTAGACATAAG) primers using Advantage 2 PCR Polymerase Mix (Clontech). The purified DNA was polished with Pfu polymerase (Stratagene, La Jolla, CA) and directionally cloned into the Invitrogen's Gateway Entry vector pENTR/D-TOPO. The entire cloned fragment was sequenced to confirm the integrity of the cDNA sequence before transferring into the Gateway Destination vector pDEST8 by in-vitro recombination using Clonase II (Invitrogen). The pDEST8-cadherin-like cDNA construct was then used to transform Escherichia coli Bac10 hosts for the generation of recombinant baculovirus constructs to be used for transfection, infection and expression in Sf21 cells (Gateway Baculovirus Expression System, Invitrogen). For expression analysis, aliquots of cells were pelleted and lysed in $1 \times$ SDS sample buffer and separated on $4-10 \%$ Tricine SDS-PAGE gels (Invitrogen). Proteins on the gel were transferred to polyvinylidene difluoride membrane and stained with an affinity-purified polyclonal antibody (diluted $1: 5000$ ) that was raised in rabbit against the carboxy terminal 22 amino acid peptide (GIENNPEFDYNFNTNEDKTTYL). Blots were washed and developed with the WesternBreeze kit for anti-rabbit antibody (Invitrogen) according to the supplied protocol.

\section{Amplification of Mexican corn rootworm cadherin-like $c D N A$}

The MCR total RNA was isolated from adult gut tissues using TrizolPlus (Invitrogen). Five micrograms of RNA was reverse transcribed in a $100 \mu$ reaction using SMART cDNA Amplification Kit (Clontech) according to the product insert. One microlitre of the reaction was used as a template for a $50 \mu \mathrm{l} \mathrm{PCR}$ that included forward (5'-TACTTGTTGGGCTCATGATGGTGTG) and reverse primers (5'-AATCGTCGTCATGAGCTTGAGCGGTGAC) designed from the WCR cadherin-like cDNA sequence, $10 \mathrm{mM}$ each dNTP and $1 \times$ Advantage cDNA Polymerase Mix (Clontech). PCR cycling parameters were: $94^{\circ} \mathrm{C}$ for $1 \mathrm{~min}$, followed by 40 cycles of $94{ }^{\circ} \mathrm{C}$ for $30 \mathrm{~s}, 60^{\circ} \mathrm{C}$ for $30 \mathrm{~s}$, and $68^{\circ} \mathrm{C}$ for $3 \mathrm{~min}$, with a final incubation for 10 min at $72{ }^{\circ} \mathrm{C}$. The PCR product was cloned in a TOPO vector and sequenced.

\section{Northern analysis}

Standard rearing techniques (Jackson, 1986) were used to obtain 50-100 mg of first, second, and third instars, pupae and adult WCR which were frozen at $-80^{\circ} \mathrm{C}$ until needed. Fresh total RNA was obtained as described above and used for Northern blotting analysis. A DIG-labelled cDNA probe was designed from the cadherin-like sequence to produce a $722 \mathrm{bp}$ fragment using the forward primer 5'-ACACACCATGCAATACTAC-3' and reverse primer 5'GTGCTAAAATTATACGATCTCG-3'. The specificity of the Diabrotica cadherin-like cDNA probe was verified by sequencing. The DIGlabelled actin control probe was amplified from a $D$. v. virgifera cDNA mix using the forward primer: 5'-TCAGGGTGTGATGGTAGG-3' and reverse primer: 5'-CTCTTTCTGCTGTGGTGGTG-3' to generate a 560 bp fragment. The probes were generated by DIG PCR labelling using the DIG PCR labelling kit (Roche Applied Science, Indianapolis, IN, USA). Samples of total RNA $(7.5 \mu \mathrm{g})$ were separated by denaturing electrophoresis on a $1.2 \%$ agarose/formaldehyde gel. The RNAs were transferred overnight on to positively charged Nylon membranes (Roche Applied Science) by capillary blotting using DEPC-treated $20 \times$ SSC transfer buffer $(3.0 \mathrm{M} \mathrm{NaCl}, 0.3 \mathrm{M}$ sodium citrate, $\mathrm{pH} 7.0$ ) and irreversibly fixed in a baking oven at $80^{\circ} \mathrm{C}$ for $2 \mathrm{~h}$. The blot was prehybridized for $1 \mathrm{~h}$ at $50^{\circ} \mathrm{C}$ in $5 \mathrm{ml}$ of hybridization solution (DIG Easy hyb, Roche Applied Science). After adding the denatured probe to a fresh hybridization solution, the membrane was hybridized overnight at $50^{\circ} \mathrm{C}$ with continuous shaking. The blot was rinsed three times in $2 \times$ SSC, $0.1 \%$ SDS at room temperature and three times with $0.5 \times \mathrm{SSC}, 0.1 \%$ SDS at $68^{\circ} \mathrm{C}$ to eliminate nonspecific hybridizations. The membrane was washed briefly in washing buffer (maleate buffer, $0.3 \%$ Tween-20), blocked for $1 \mathrm{~h}$ in $0.5 \times$ blocking buffer (Roche Applied Science) and then incubated with anti-DIG at $1: 15000$ dilution in blocking buffer for $45 \mathrm{~min}$. The membrane was washed four times (15 min each) with washing buffer, briefly washed with detection buffer (Roche Applied Science) for $5 \mathrm{~min}$, and incubated with the chemiluminescent substrate for alkaline phosphatase (CSPD, Tropix Inc., Bedford, MA, USA) for $5 \mathrm{~min}$. The blot was exposed to chemiluminescence Biomax film (Kodak, Rochester, NY) at room temperature for $25 \mathrm{~min}$. The membrane was stripped and reprobed with $D . v$. virgifera DIG-labelled actin probe (560 bp) to standardize loadings.

\section{Genome walking}

The cDNA sequence information was used as a starting point to characterize the genomic structure of the cadherin-like gene. Exonintron boundaries were determined by cloning and sequencing of PCR amplified products using exon-specific primers. RNA splicing junctions were defined by comparing genomic and corresponding cDNA sequences. For this, four genomic libraries were generated from adult WCR genomic DNA that had been cut with different restriction enzymes (EcoRV, Pvull, Stul and Dral) and ligated to an adaptor oligo using the Genome Walking kit (Clontech). These ligated DNA pools were then used as templates for two rounds of PCR. Primary and nested PCRs were performed using kit primers complementary to the adaptor sequences and gene-specific sense and anti-sense primers that were designed based on the cloned cDNA sequence. Each PCR mixture contained $2.5 \mu \mathrm{M}$ of 
dNTPs, $1 \times$ Advantage buffer and 1.25 units of Advantage Polymerase Mix (Clontech) in a $50 \mu \mathrm{l}$ reaction. For the nested PCRs, $1 \mu \mathrm{l}$ of 50 -fold diluted primary PCR product was used as a template. Amplicons derived from each set of primers were directly sequenced or subcloned into the TOPO vector and then sequenced.

\section{Sequence analysis}

DNA sequencing was performed with a $3730 X L$ Genetic Analyzer (Applied Biosystems). Sequence editing was done with Sequencher software (Gene Codes, Ann Arbor, Ml). Sequence searches, alignments and other sequence analyses were performed using NCBI BLAST programs. Putative transcription factor sites were identified by the Matlnspector program (http://www.genomatix.de). The ORF Finder (http://www.ncbi.nlm.nih.gov/gorf/gorf.html) was used for deducing polypeptide sequences. Protein domains were predicted using the Simple Modular Architecture Research Tool (SMART) (http:// smart.embl-heidelberg.de) and MotifScan (http://myhits.isb-sib.ch/ cgi-bin/motif_scan). Phylogenetic analyses were performed with AlignX (Vector NTI-Invitrogen Life Technology).

\section{Acknowledgements}

We thank Suzanne Jackson, and Dr. George King for helpful discussions. DNA sequencings were performed by Barry Wiechman and Melinda Ostendorf. Technical supports were also provided by Analiza Alves and Mark Smith. The United States Environmental Protection Agency through its Office of Research and Development partially funded and collaborated in the research described here under Contract EPD06096 to Dynamac Corporation. It has been subjected to Agency review and approved for publication. Mention of trade names or commercial products does not constitute endorsement or recommendation for use.

\section{References}

Andrews, G.L. and Mastik, G.S. (2003). R-cadherin is a pax6regulated, growth-promoting cue for pioneer axons. J Neurosci 23: 9873-9880.

Behrens, J., Lowrick, O., Klein-Hitpass, L. and Birchmeier, W. (1991) The E-cadherin promoter: functional analysis of a G.C.rich region and an epithelial cell-specific palindromic regulatory element. Proc Natl Acad Sci USA 88: 11495-11499.

Bel, Y. and Escriche, B. (2006) Common genomic structure for the Lepidopteran cadherin-like genes. Gene 381: 71-80.

Bowler, T., Kosman, D., Licht, J.D. and Pick, L. (2006). Computational identification of Ftz/Ftz-F1 downstream target genes. Dev Biol 299: 78-90.

Bravo, A., Gomez, I., Conde, J., Munoz-Garay, C., Sanchez J, Miranda, R., et al. (2004) Oligomerization triggers binding of a Bacillus thuringiensis Cry1 $\mathrm{Ab}$ pore-forming toxin to aminopeptidase $\mathrm{N}$ receptor leading to insertion into membrane microdomains. Biochim Biophys Acta 1667: 38-46.

Dorsch, J.A., Candas, M., Griko, N.B., Maaty, W.S.A, Midboe, E.G., Vadlamudi, R.K., et al. (2002) Cry1A toxins of Bacillus thurigiensis bind specifically to a region adjacent to the membrane-proximal extracellular domain of BT-R1 in Manduca sexta: involvement of a cadherin in the entomopathogenicity of Bacillus thurigiensis. Insect Biochem Mol Biol 32: 1025-1036.

Ellis, R.T., Stockhoff, B.A., Stamp, L., Schnepf, H.E., Schwab, G.E., Knuth, M., et al. (2002) Novel Bacillus thuringiensis binary insecticidal crystal proteins active on western corn rootworm, Diabrotica virgifera virgifera LeConte. Appl Environ Microbiol 68: $1137-1145$.

Environmental Protection Agency (2003) Bacillus thuringiencis Cry3Bb1 Protein and the genetic material necessary for its production (cector ZMIR13L) in event MON863 Corn Fact Sheet. EPA Publication Number 730-F-03-01.

Faraldo, M.L. and Cano, A. (1993) The $5^{\prime}$ flanking sequences of the mouse P-cadherin gene. Homologies to $5^{\prime}$ sequences of the E-cadherin gene and identification of a first 215 base-pair intron. J Mol Biol 231: 935-941.

Gahan, L.J., Gould, F. and Heckel, D.G. (2001) Identification of a gene associated with $\mathrm{Bt}$ resistance in Heliothis virescens. Science 293: 857-860.

Godt, D. and Tepass, U. (1998) Drosophila oocyte localization is mediated by differential cadherin-based adhesion. Nature 395: 387-391.

Gómez, I., Miranda-Rios, J., Ridiño-Piñera, E., Oltean, D.I., Gill, S.S., Bravo, A., et al. (2002a) Hydropathic complementarity determines interaction of epitope 869HITDTNNK876 in Manduca sexta Bt- $\mathrm{R}_{1}$ receptor with loop 2 of domain II of Bacillus thuringiensis Cry1A toxins. J Biol Chem 277: 3037-30143.

Gómez, I., Sánchez, J., Miranda, R., Bravo, A. and Soberón, M. (2002b) Cadherin-like receptor binding facilitates proteolytic cleavage of helix $\alpha-1$ in domain I and oligomer pre-pore formation of Bacillus thuringiensis Cry1Ab toxin. FEBS Lett 513: 242246.

Gómez, I., Dean, D.H., Bravo, A. and Soberón, M. (2003) Molecular basis for Bacillus thuringiensis Cry1 Ab toxin specifity: two structural determinants in the Manduca sexta Bt $\mathrm{R}_{1}$ receptor interact with loops $\alpha-8$ and 2 in domain II of Cry $1 \mathrm{Ab}$ toxin. Biochemistry 42: 10482-10489.

Griffitts, J.S. and Aroian, R.V. (2005) Many roads to resistance: how invertebrates adapt to Bt toxins. BioEssays 27: 614624.

Gumbiner, B.M. (2005) Regulation of cadherin-mediated adhesion in morphogenesis. Nat Rev Cell Mol Biol 6: 622-634.

Hernstadt, C., Soares, G.C., Wilcox, E.R. and Edwards, D.L. (1986) A new strain of Bacillus thuringiensis with activity against coleopteran insects. Bio/Technology 4: 305-308.

Hernstadt, C., Gilroy, T.E., Solesk, D.A., Bennet, B.D. and Gautner, F.H. (1987) Nucleotide sequence and deduced amino acid sequence of a coleopteran active delta-endotoxin gene from Bacillus thuringiensis subp. san diego. Gene 57: 81-116.

Jackson, J.J. (1986) Rearing and handling of Diabrotica virgifera and Diabrotica undecimpunctata howardi. In Methods for the Study of Pest Diabrotica (Krysan, J.L. and Miller, T.A., eds), pp. 25-47. Springer, New York.

Krieg, A., Huger, A.M., Langenbruch, G.A. and Schenetter, W. (1983) Bacillus thuringiensis var. tenebrionis: ein neuer, gegenüber Laven von Coleopteren wirksamer Pathotype, Z. Angew. Entomology 96: 500-508.

Kumar, S., Tamura, K. and Nei, M. (2004) MEGA3: integrated software for molecular evolutionary genetics analysis and sequence alignment. Brief Bioinform 5: 150-163.

Levine, E. and Oloumi-Sadeghi, H. (1991) Management of diabroticite rootworms in corn. Annu Rev Entomol 36: 229-255. 
Levine, E., Spencer, J.L., Isard, S.A., Onstad, D.W. and Gray, M.E. (2002) Adaptation of the western corn rootworm to crop rotation: evolution of a new strain in response to a management practice. Am Entomol 48: 94-107.

Liang, Z. and Biggin, M.D. (1998). Eve and ftz regulate a wide array of genes in blastoderm embryos: the selector homeoproteins directly or indirectly regulate most genes in Drosophila. Development 125: 4471-4482.

Meinke, L.J., Siegfried, D., Wright, R.J. and Chandler, L.D. (1998) Adult susceptibility of Nebraska western corn rootworm (Coleoptera: Chrysomelidae) populations to selected insecticides. $J$ Econ Entomol 91: 594-600.

Moellenbeck, D.J., Peters, M.L., Bing, J.W., Rouse, J.R., Higgins, L.S., et al. (2001)Insecticidal proteins from Bacillus thuringiensis protect corn from corn rootworms. Nat Biotechnol 19: 668672.

Morin, S., Biggs, R.W., Sisterson, M.S., Shriver, L., Ellers-Kirk, C., et al. (2003)Three cadherin alleles associated with resistance to Bacillus thuringiensis in pink bollworm. Proc Natl Acad Sci USA 100: 5004-5009.

Nagamatsu, Y., Toda, S., Yamaguchi, F., Ogo, M., Kogure, M., Nakamura, M., et al. (1998a) Identification of Bombyx mori midgut receptor for Bacillus thuringiensis insecticidal CrylA(a) toxin. Biosci Biotechnol Biochem 62: 718-726.

Nagamatsu, Y., Toda, S., Koike, T., Miyoshi, Y., Shigematsu, S. and Kogure, M. (1998b) Cloning, sequencing, and expression of the Bombyx mori receptor for Bacillus thuringiensis insecticidal CrylA(a) toxin.cell-specific activity. Biosci Biotechnol Biochem 62: $727-734$.

Nagamatsu, Y., Koike, T., Sasaki, K., Yoshimoto, A. and Furukawa, Y. (1999) The cadherin-like protein is essential to specificity determination and cytotoxic action of the Bacillus thuringiensis insecticidal CrylAa toxin. FEBS Lett 460: 385-390.

Nowatzki, T.M., Zhou, X., Meinke, L.J., Vaughn, T. and Siegfried, B.D. (2006) Effect of Bacillus thuringiensis cry3Bb1 protein on the feeding behavior and longevity of adult western corn rootworms (Coleoptera: Chrysomelidae). J Econ Entomol 99: 927-930.

Parimi, S., Scharf, M.E., Meinke, L.J., Chandler, L.D. and Siegfried, B.D. (2003) Inheritance of methyl-parathion resistance in Nebraska western corn rootworm populations (Coleoptera: Chrysomelidae). J Econ Entomol 96: 131-136.
Rausell, C., Garcia-Robles, I., Sanchez, J., Munoz-Garay, C. Martinez-Ramirez, A.C., Real, M.D., et al. (2004) Role of toxin activation on binding and pore formation activity of the Bacillus thuringiensis Cry3 toxins in membranes of Leptinotarsa decemlineata (Say). Biochim Biophys Acta 1660: 99-105.

Schnepf, E., Crickmore, N., Van Rie, J., Lereclus, D., Baum, J., Feitelson, J., et al. (1998) Bacillus thuringiensis and its pesticidal crystal proteins. Microbiol Mol Biol Rev 62: 775-806.

Sick, A., Gaertner, F. and Wong, A. (1990) Nucleotide sequence of a coleopteran-active toxin gene from a new isolate of Bacillus thurigiensis subp. tolworthi. Nucleic Acids Res 18: 1305.

Siegfried, B.D., Meinke, L.J., Parimi, S., Scharf, M.E., Nowatzki, T.J., Zhou, X., et al. (2004) Monitoring western corn rootworm (Coleoptera: Chrysomelidae) susceptibility to carbaryl and cucurbitacin baits in the areawide management pilot program. $J$ Econ Entomol 97: 1726-1733.

Siegfried, B.D., Waterfield, N. and ffrench-Constant, R.H. (2005) Expressed sequence tags from Diabrotica virgifera virgifera midgut identify a coleopteran cadherin and a diversity of cathepsins. Insect Mol Biol 14: 137-143.

Silos, S.A., Tamai, K., Li, K., Kivirikko, S., Kouba, D., Christiano, A.M., et al. (1996) Cloning of the gene for human pemphigus vulgaris antigen (desmoglein 3), a desmosomal cadherin. Characterization of the promoter region and identification of a keratinocytespecific cis-element. J Biol Chem 271: 17504-17511.

Tsuda, Y., Nakatani, F., Hashimoto, K., Ikawa, S., Matsuura, C., Fukada, T., et al. (2003) Cytotoxic activity of Bacillus thuringiensis Cry proteins on mammalian cells transfected with cadherin-like Cry receptor gene of Bombyx mori (silkworm). Biochem J 369: 697-703.

Vadlamudi, R.K., Ji, T.H. and Bulla, L.A. Jr (1993). A specific binding protein from Manduca sexta for the insecticidal toxin of Bacillus thuringiensis subsp. berliner. J Biol Chem 268: 12334-12340.

Vadlamudi, R.K., Weber, E., Ji, I., Ji, T.H. and Bulla, L.A. Jr (1995) Cloning and expression of a receptor for an insecticidal toxin of Bacillus thuringiensis. J Biol Chem 270: 5490-5494.

Whyte, D.A., Li, C., Thomson, R.B., Nix, S.L., Zanjani, R., Karp, S.L., et al. (1999) Ksp-cadherin gene promoter. I. Characterization and renal epithelial cell-specific activity. Am J Physiol 277: F587-F598. 